\title{
CHARACTERISTIC OF SIPHONIC ROOF DRAINAGE SYSTEM - PRINCIPLES AND DESIGN CONDITIONS
}

\author{
Ing. Lenka J ágerská; Doc. Ing. J ana Peráčková, Ph.D.
}

\section{ABSTRACT}

Amount and intensity of rainfalls are increasingly changing by clime changing and increasing of temperature variations. There is increase of torrential rains, which extremely burden the construction by the huge volume of rainwater and thus effect on whole building construction. It is necessary safely lead away this amount of rainfalls to remain the building construction undamaged. The method of roof drainage mostly depends on the roof construction. Flat roofs are more sensitive to torrential rains, thus there is very important to make proper design of drainage system and location of roof runoffs. There is no Standard for dimensioning the Siphonic roof drainage system in Slovakia. In this article is shown general procedure of design the siphonic roof drainage system, based on rules contained in the German technical regulation VDI 3806 - Dachentwässerung with Druckströmung.

Key words: siphonic drainage, flat roof drainage, calculation procedure

\section{DIFFERENCES BETWEEN GRAVITY DRAINAGE SYSTEM AND SIPHONIC DRAINAGE SYSTEM}

Difference between gravity and siphonic system is shown on picture below. (Fig. 1)

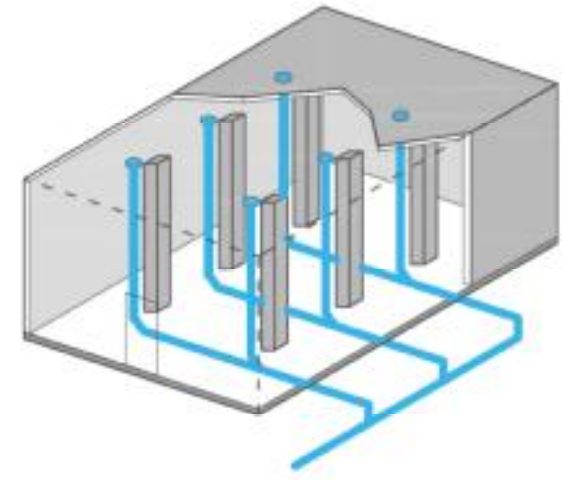

GRAVITY DRAINAGE SYSTEM

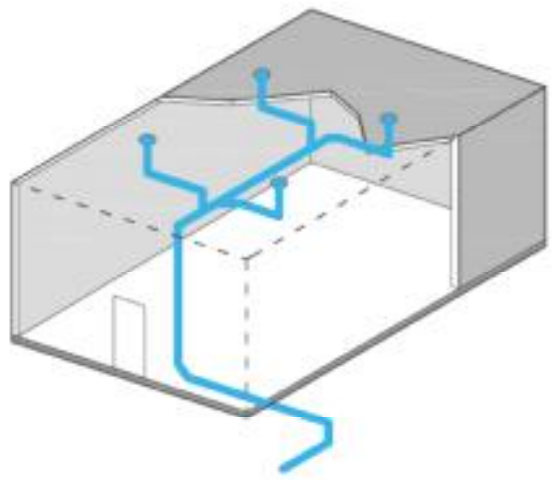

SIPHONIC DRAINAGE SYSTEM

Fig. 1 The difference between gravity and siphonic drainage system

- A smaller number of roof runoffs. There is needed larger number of roof runoffs in gravity system comparison with siphonic system. Gravity roof runoffs have lower flow rate, that is caused by air in the gravity pipeline, wherein water constitutes $70 \%$ of the pipe cross-section, and the rest is filled with air. In the siphonic system, there are roof runoffs designed to prevent entry the air in the pipe, therefore the pipes are totally filled with water (Fig. 2). Also in the same roof area, there are smaller dimensions of roof piping.

- Material saving. The gravity system has its own separate drain from every roof runoff but the siphonic system has only one collecting pipe, that lead rain water from all runoffs to one drain pipe (Fig. 2). 
- Easier layout solution. The siphonic piping is led without slope, that allows lead the piping under the roof for long distances. (Fig. 3).
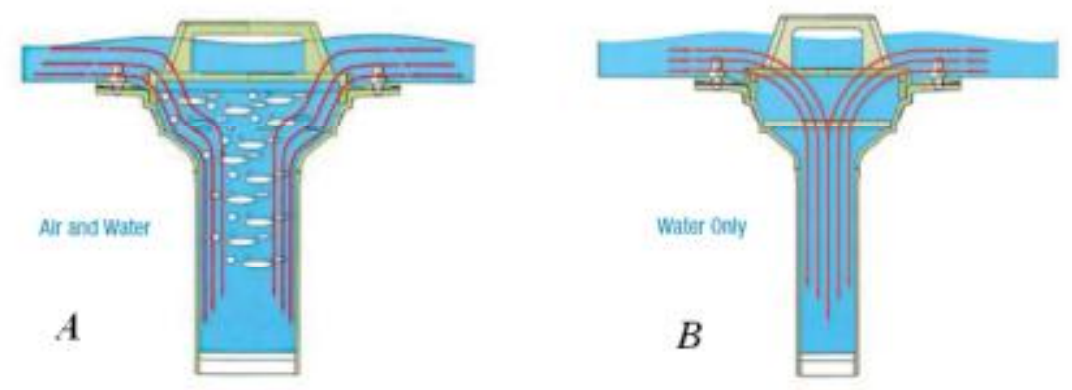

Fig. 2 Difference between gravity and siphonic roof runoff [9] A - gravity roof runoff with air, B - siphonic roof runoff without air.

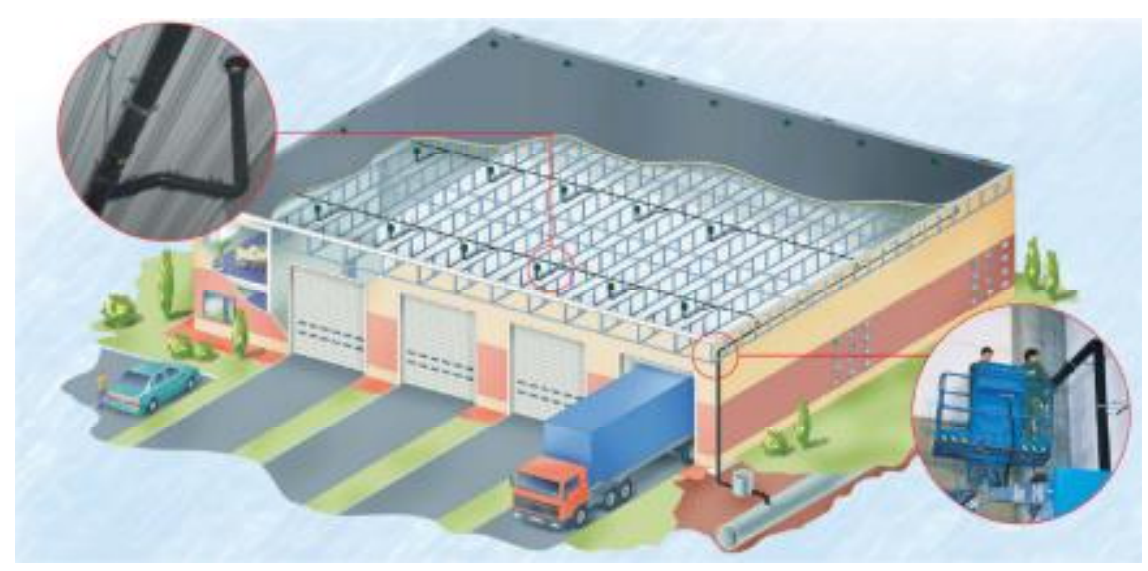

Fig. 3 Example of flat roof drainage by siphonic system [7]

\section{DESIGN PRINCIPLES}

Siphonic roof drainage system works on a full bore flow, because of this, it is considered higher rainfall rate in comparison with gravity drainage system. Full bore flow is achieved by using special types of roof runoffs suitable for siphonic systems and by proper hydraulic calculation. A negative pressure in full bore flow occurs by the action of gravity on mass of water in pipes creating a pressure difference between roof drains and the transition to gravity drainage. Once the negative pressure starts it is continuing by itself until it has appropriate conditions. These principles should be followed in the design [4]:

- all troughs in the roof must be fitted with at least one runoff (Chyba! Nenalezen zdroj odkazů.),

- large roof surfaces (over $5000 \mathrm{~m}^{2}$ ) must be drained by at least two independent siphon drainage systems,

- in the transition area from a siphon to an open drainage system, the high kinetic energy of the siphon pressure must be converted by reducing the velocity of flow to $\mathrm{v}<2,5 \mathrm{~m} / \mathrm{s}$,

- the combination of roof areas with different discharge time lags (coefficients of discharge), e.g. in the case of intensively planted roofs, extensively planted roofs, gravel-covered and non-gravelcovered roofs, in one siphon drainage system is to be avoid,

- roofs areas with extremely differing pitches or on very different levels should not be drained via a single downpipe, 
- the roof runoffs on green roofs are to be protected by means of inspection shaft or surrounded by a strip of gravel at least $50 \mathrm{~cm}$ wide protected by a leaf trap grille should be protected by inspection shaft or should be surrounded by $50 \mathrm{~cm}$ gravel border.

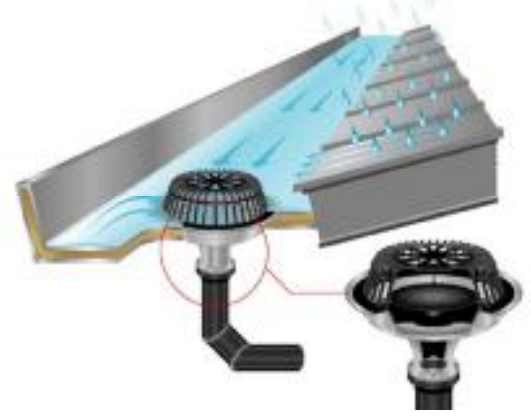

Fig. 4 Siphonic roof runoff set in gutter [10]

\section{CALCULATION PROCEDURE}

For the dimensioning of roof drainage system with siphon action, the rain volume flow $\left(\mathrm{Q}_{\mathrm{r}} \mathrm{v} \mathrm{l} / \mathrm{s}\right)$ which is fed into the drainage system, when the reference rainfall rate $\left(\mathrm{r} v \mathrm{l} /\left(\mathrm{s} \mathrm{m}^{2}\right)\right)$ occurs, is decisive. The proportion of rainfall which actually runs off depends on the shape and surface properties of the surface on which it falls and the flow conditions. [4] The rain volume flow is calculated by:

$$
Q_{r}=r \cdot C \cdot \mathrm{A}
$$

where:

$r \quad$ - reference rainfall rate, by [5] is $0,030 \mathrm{l} /\left(\mathrm{s}_{\mathrm{m}} \mathrm{m}^{2}\right)$,

C - coefficient of drainage, by [6], (tab. 1),

A - the surface area in $\mathrm{m}^{2}$, on which rain will fall, as projected in the ground plan, (Fig. 5).

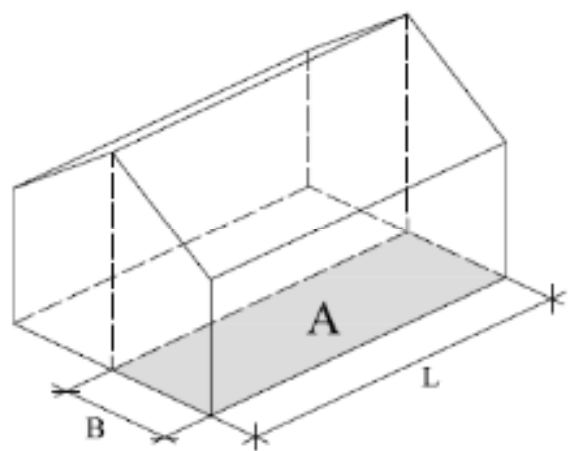

Fig. 5 The surface area „A“( $A=B$. $L$ in $\mathrm{m}^{2}$, where $L$ is length of roof gutter and $B$ is plan projection of the roof gutter to the ridge) [1]

\begin{tabular}{|l|c|}
\hline \multicolumn{1}{|c|}{ Types of drainage areas } & Coefficient of drainage C (-) \\
\hline \hline Roofs, balconies, terraces ${ }^{\text {a) }}$ & 1,0 \\
\hline Roofs with permeable upper layer thicker & 0,5 \\
\hline${ }^{\text {a) }}$ for flat roofs of over $10000 \mathrm{~m}^{2}$ the coefficient of drainage may be considered as $\mathrm{C}=0,8$ \\
\hline
\end{tabular}

Tab. 1 Coefficient of drainage [6]

When the rain volume flow of a roof surface $Q_{r}$ is known, the necessary number of roof runoffs is designed as: 


$$
n_{v}=\frac{Q_{r}}{V_{v}}
$$

where:

$Q_{r} \quad$ - calculated rain volume flow in 1/s by (1),

$V_{v} \quad$ - estimated capacity of roof runoff given by producer in 1/s.

Minimal number of roof runoffs, rounded to the nearest whole number (axial distance between the roof runoffs must not exceed 20 metres) [4]

The basis for the hydraulic calculation of roof drainage with a siphon system is Bernoulli's equation for a steady flow of an incompressible fluid with constant density. This state of flow is only achieved in operated completely full without any air input [4].

The flow path with connection of all roof runoffs is designed after determining the number of roof runoffs and its location on roof surface. The available pressure in flow path is calculated as:

$$
\Delta p_{\text {disp }}=\Delta h_{\text {disp }} \cdot \rho \cdot g
$$

where:

$\Delta h_{\text {disp }}$ - difference in level in $\mathrm{m}$ between roof lining and partially filled pipeline, (the transition to gravity drainage system),

$\rho \quad-$ density of water at $10{ }^{\circ} \mathrm{C}$ is $1000 \mathrm{~kg} / \mathrm{m}^{3}$,

g - gravity acceleration $9.81 \mathrm{~m} / \mathrm{s}^{2}$.

The calculation of pressure losses starts in the most unfavourable (the longest) flow path. The pressure loss difference in parts following in a row along the flow path must not exceed $10 \mathrm{kPa}(100$ mbar). Preliminary pressure losses $R_{p r}$ at $1 \mathrm{~m}$ of pipes in the most unfavourable flow path are:

$$
R_{p r}=\frac{\Delta p_{\text {disp }}}{1,2 \cdot l_{\text {tras }}} \quad(\mathrm{Pa} / \mathrm{m})
$$

where:

$\Delta p_{\text {disp }}$ - the available pressure in flow path in $\mathrm{Pa}$,

$l_{\text {tras }}-$ total length of the longest flow path (pipe) in m,

1,2 - coefficient comprising the expected pressure losses as $20 \%$ of 1.R.

The dimension of each part of the pipes are designed by design diagram for the chosen type of material [4] through calculated rain volume flow $Q_{r}$ calculated by equation (1) and through preliminary pressure losses $R_{p r}$ calculated by equation (4).

The real pressure losses in parts of flow path are calculated by equation:

$$
\Delta p=\sum(l \cdot R+Z)
$$

where:

$l \quad-$ the length of part of flow path in $\mathrm{m}$,

$R \quad$ - linear pressure loss due to pipe friction determined according to the type of pipe material in $\mathrm{Pa} / \mathrm{m}$, set by the design diagram of piping producer, 
$Z \quad-$ pressure loss due to local resistance in $\mathrm{Pa} / \mathrm{m}$ calculated by equation (6).

$$
Z=\sum \zeta \cdot \frac{v^{2} \cdot \rho}{2} \quad(\mathrm{~Pa} / \mathrm{m})
$$

where:

$\zeta \quad$ - isolated drag coefficient, (tab. 2),

$v \quad-$ the real flow velocity in pipes in $\mathrm{m} / \mathrm{s}$, set by the design diagram of piping producer,

$\rho \quad-$ density of water at $10{ }^{\circ} \mathrm{C}$ is $1000 \mathrm{~kg} / \mathrm{m}^{3}$.

\begin{tabular}{|l|c|}
\hline \multicolumn{1}{|c|}{ Pipe fitting } & $\zeta(-)$ \\
\hline \hline bend $15^{\circ}$ & 0,1 \\
\hline bend $30^{\circ}$ & 0,3 \\
\hline bend $45^{\circ}$ & 0,4 \\
\hline bend $70^{\circ}$ & 0,6 \\
\hline bend $90^{\circ}$ & 0,8 \\
\hline reduction & 0,3 \\
\hline Y-branch & 0,6 \\
\hline Transition to partially filled pipe & 1,8 \\
\hline
\end{tabular}

Tab. 2 Isolated drag coefficient $\zeta$ of curved and branches [4]

A reduction of the pipeline in the direction of flow for hydraulic reasons is permitted, but as rule should be adopted only in downpipes or vertical pipes. An enlargement of the diameter over the course of downpipe generally leads to a breakdown in siphon system and for that reason should definitely by avoided.

When determining the diameter for siphon drainage system the smallest permitted bore is DN 40 (minimal internal diameter $32 \mathrm{~mm}$ ). To ensure the self-cleaning effect in the pipes, the minimum flow velocity should be more than $\mathrm{v}=0,7 \mathrm{~m} / \mathrm{s}$. [4]

In the hydraulic calculations, the numerical value for the vacuum pressure must not be less than $90 \mathrm{kPa}$. If the calculated value of vacuum is lower than $-90 \mathrm{kPa}$, there is a risk of cavitation flow (bubbles of air in the pipes) and therefore the desired efficiency of system could not be achieved. Estimated internal pressure (vacuum) is calculated for each part of flow path as:

$$
p_{i}=\Delta h_{i} \cdot \rho \cdot g-\frac{v_{i}^{2} \cdot \rho}{2}-\Sigma(l \cdot R+Z)_{\ldots i}
$$

The operating pressure in pipes given by producer should be taken in to consideration in the final design [4].

\section{CONCLUSION}

The design of siphonic roof drainage system is based on hydraulic fluid flow. If all conditions of design are followed there is an expectation that the proposed system will work properly. The siphonic roof drainage system is suitable for large roof surfaces, the manual calculation procedure is very laborious and cannot exclude the risk of errors. Therefore, most of designers turns to companies that ensure correct design of this system and also guarantees their system. 


\section{Literature}

[1] PERÁČKOVÁ, Jana - JÁGERSKÁ, Lenka [Laščeková, Lenka]. Podtlakový systém odvodnenia striech. In TZB Haustechnik. Roč. 19, č. 4 (2011), s. 42-44. ISSN 1210-356X

[2] LAŠČEKOVÁ, Lenka: Navrhovanie podtlakového systému odvodnenia striech. In Sanhyga 2010: 15.medzinárodná konferencia/Piešt’any, 14.-15.10.2010. Bratislava: Slovenská spoločnost' pre techniku prostredia ZSVTS, 2010, s.107-116. ISBN 978-80-89216-35-2

[3] VALÁŠEK, Jaroslav.: Úpravy pre bezpečné odvodnenie striech, TZB Haustechnik. č.3 (2008)

[4] VDI 3806 Dachentwässerung mit Druckströmung, 2000

[5] STN EN 12056-3:2002 Gravitačné kanalizačné systémy vnútri budov. Čast' 3: Odvodnenie striech. Navrhovanie a výpočet

[6] STN 736760 - Kanalizácia v budovách. 2009

[7] Catalog: Akatherm Sison - Vákuový systém odvodnení střech

[8] Keidel GmbH, Learning Siphonic Roof Drainage, http://www.learning-siphonic-roofdrainage.com/contents.html

[9] Catalog: ZURN Siphonic Drain System, www.zurn.com

[10] Catalog: Fullflow Group Limited, http://www.fullflow.com/

[11] Catalog: WAVIN Ekoplastik s.r.o., http://www.wavin.cz/ 